\title{
Membrane-Associated Guanylate Kinase, WW and PDZ Domain-Containing Protein 1
}

National Cancer Institute

\section{Source}

National Cancer Institute. Membrane-Associated Guanylate Kinase, WW and PDZ

Domain-Containing Protein 1. NCI Thesaurus. Code C28718.

Membrane-associated guanylate kinase, WW and PDZ domain-containing protein 1 (1491 aa, $165 \mathrm{kDa}$ ) is encoded by the human MAGl1 gene. This protein is involved in protein complex formation at cell-cell junctions. 